\title{
Biochemical composition of some marine fish species of Ghana
}

\author{
E. A. OBODAI ${ }^{1 *}$, L. D. ABBEY ${ }^{2}$ and C. MacCARTHY ${ }^{2}$ \\ ${ }^{1}$ Department of Fisheries and Aquatic Sciences, U.C.C, Cape Coast, Ghana. \\ ${ }^{2}$ Food Research Institute, Accra, Ghana \\ Corresponding author, E-mail: obodai254@yahoo.com
}

\begin{abstract}
The biochemical compositions of five commercial marine fish species (Chloroscombus chrysurus, Pseudotolithus senegalensis, Sardinella aurita, Scombus japonicus and Syacium micurum) landed at the Elmina landing quay were analyzed using standard analytical techniques. The results indicate significant differences among the biochemical compositions of the five fish species studied. Moisture content ranged from $72.36 \%$ in S. japonicus (chub mackerel) to $79.06 \%$ in S. micurum (the sole fish). The least protein content (16.71\%) was observed in S. micurum and the highest of $22.53 \%$ in S. japonicus. The fat content was highest for S. japonicus (15.27\%) and lowest for S. micurum (3.10\%). In all the five fish species studied, calcium content was highest, followed by phosphorus and iron content was the least. P. senegalensis (cassava fish), however, had higher phosphorus than calcium content. $S$. micurum is therefore recommended for people with over-weight (obesity) problem.

(C) 2009 International Formulae Group. All rights reserved.
\end{abstract}

Keywords: Biochemical, marine, commercial species, fish, Ghana.

\section{INTRODUCTION}

Fish is a first class protein source that contains all the essential amino acids in their right proportion, other nitrogenous compounds, water, lipids, carbohydrates (as glycogen), minerals and vitamins. Fish diet has high commercial and medicinal values (Nunes et al., 1992).

The five fish species studied $(C$. chrysurus, $P$. senegalensis, $S$. aurita, $S$. japonicus and $S$. micurum) are among the most popular food fishes landed at the Elmina harbour. Thus even though they are widely eaten, their food values are not known. Knowing the nutritional status of fish species usually eaten by the people could contribute to remedying problems of malnourishment and obesity. The objective of this study was to determine the biochemical composition of the five marine fish species. The components investigated were moisture, protein, fat, ash, carbohydrates, calcium, iron and phosphorus.

\section{MATERIALS AND METHODS \\ Study area}

The study was conducted at Elmina fish landing quay. Elmina lies between latitudes $5^{0}$ and $5^{0} 30^{1} \mathrm{~N}$ and longitudes $1^{0} 15^{1}$ and $1^{0}$ $30^{1} \mathrm{~W}$. It is $10 \mathrm{~km}$ Southwest of the Cape Coast, the capital city of the Central Region of Ghana.

\section{Collection and preservation of fish samples}

Fresh samples of the five fish species were obtained from the Elmina fish landing quay. Each species was placed in a labelled, transparent polyethylene bag, and put on ice in an ice chest, and sent to the Food Research Institute Accra for analysis.

\section{Sample preparation and analysis}

The frozen fish samples were removed from the chest and allowed to thaw. The head, tail, fins, viscera and skin of each fish were 
removed. The fillet was scrapped with a knife into a mortar and mashed until a uniform mixture was produced. The mixture was stored in a refrigerator, and later divided into two portions. One portion was used for the determination of proximate analysis and was oven-dried at $50{ }^{\circ} \mathrm{C}$ overnight and used for percentage protein, fat and ash (i.e. analysis of proximate composition and mineral content, based on AOAC (1990)). The ash content was then used for the determination of calcium, iron and phosphorus contents.

The portion for moisture determination was placed in a Gallenkamp oven at $105{ }^{\circ} \mathrm{C}$ overnight to obtain a constant weight. It was removed and allowed to cool in a desiccator and weighed. The difference between the wet and dry weights gave the moisture content. Protein content was determined by estimating the total nitrogen using the macro-Kjeldahl method (AOAC, 1990) and multiplying the value by 6.25 . Fat was extracted by the continuous Soxhlet extraction method (AOAC, 1990), while the ash content was determined by igniting $5 \mathrm{~g}$ of the dry meat to ash in a muffle furnace at $550{ }^{\circ} \mathrm{C}$. Carbohydrate was obtained by the subtraction of protein, fat and ash values from 100 .

The concentrations of three major minerals (calcium, iron and phosphorus) in the 5 fish species were determined by the methods outlined by Eyeson and Ankrah (1975).

\section{RESULTS}

\section{Moisture and nutritional contents}

The results (Table 1) indicate that with the exception of the ash content, the variations in the proximate contents of the five fish species were significant $(\mathrm{p}<0.05)$. The mean moisture content, which was the highest, ranged from $72.36 \%$ in $S$. japonicus to $79.06 \%$ in $S$. micurum. Mean percentage protein content of the five fish species was lowest in S. micurum (16.71\%). The Atlantic bumber (C. chrysurus) had $18.92 \%, P$. senegalensis (19.51\%), S. aurita $(20.60 \%)$ and the $S$. japonicus had the highest mean protein content of $22.53 \%$. Mean percentage fat contents of the five fish species were generally low, with $S$. japonicus showing the highest $(15.27 \%)$, followed by $S$. aurita with $9.00 \%$, P. senegalensis had $7.45 \%$, the Atlantic bumber (C. chrysurus) $(5.30 \%)$ and
S. micurum had the least mean fat content of $3.10 \%$.

Of the proximate mean components, ash was the lowest, ranging from $1.36 \%$ in the chub mackerel to $1.72 \%$ in the round sardine. The variations in the mean ash content of the five fish species were not significant ( $p>0$ 05).

Carbohydrate contents were generally high for all the five fish species. The least mean percent content of $60.84 \%$ was recorded in S. japonicus. S. aurita had $68.66 \%, P$. senegalensis $71.65 \%$, C. chrysurus $74.20 \%$ and $S$. micurum had the highest $(78.73 \%)$.

\section{Mineral content}

The results in table 2 indicate significantly $(p<0.05)$ wide variations in the mean percentage mineral contents of the five fish species studied. With the exception of only one of the species (i.e. P. senegalensis), calcium content was highest, followed by phosphorus content and iron content in descending order.

\section{DISCUSSION}

The biochemical composition of fish varies from one species to another, depending on a number of factors including age, fishing grounds, fishing season, sex of the fish, feed intake and migratory swimming (Lall, 1994). Therefore the results obtained must be interpreted with caution. Nonetheless, fish and fishery products contain water, protein, fat, ash, carbohydrates, minerals and vitamins (Nunes et al., 1992; Lall, 1994); and according to FAO (1986), the five usual constituents measured for compositional analysis of fish are moisture, protein, fat, ash and carbohydrate which is obtained by subtraction according to the AOAC (1990) method.

The higher moisture content of all the five fish species (than other constituents) supports the fact that water is the main constituent of fishes and accounts for between 70 and $80 \%$ of the weight of the fish (Tenny et al., 1984). The values obtained in this research fall within the range quoted above by these authors for fishes. Ogunlade et al. (2005) reported that the moisture content of the muscle of fin fishes varied between 70 and $75 \%$. It is interesting to note that three of the moisture values obtained in the current study fall within this range, and the remaining two 
Table 1: Moisture and major nutritional components (\% Dry tissue) contents of five commercial fish species landed at Elmina landing quay.

\begin{tabular}{lccccc}
\hline Components & $\begin{array}{c}\text { Chloroscombus } \\
\text { chrysurus }\end{array}$ & $\begin{array}{c}\text { Syacium } \\
\text { micurum }\end{array}$ & $\begin{array}{c}\text { Sardinella } \\
\text { aurita }\end{array}$ & $\begin{array}{c}\text { Pseudotolithus } \\
\text { senegalensis }\end{array}$ & $\begin{array}{c}\text { Scomber } \\
\text { japonicus }\end{array}$ \\
\hline Moisture & 76.52 & 79.06 & 74.15 & 74.39 & 72.36 \\
Protein & 18.92 & 16.71 & 20.60 & 19.51 & 22.53 \\
Fat & 5.30 & 3.10 & 9.00 & 7.45 & 15.27 \\
Ash & 1.56 & 1.46 & 1.72 & 1.39 & 1.36 \\
Carbohydrate & 74.20 & 78.73 & 68.66 & 71.65 & 60.84 \\
\hline
\end{tabular}

Table 2: Mineral contents $(\mathrm{mg} / 100 \mathrm{~g})$ of five marine fish species.

\begin{tabular}{lccccc}
\hline Mineral Content & $\begin{array}{c}\text { Chloroscombus } \\
\text { chrysurus }\end{array}$ & $\begin{array}{c}\text { Syacium } \\
\text { micurum }\end{array}$ & $\begin{array}{c}\text { Sardinella } \\
\text { aurita }\end{array}$ & $\begin{array}{c}\text { Pseudotolithus } \\
\text { senegalensis }\end{array}$ & $\begin{array}{c}\text { Scomber } \\
\text { japonicus }\end{array}$ \\
\hline Calcium & 630.5 & 529.00 & 740.50 & 358.50 & 381.50 \\
Iron & 2.80 & 3.25 & 3.77 & 3.11 & 3.24 \\
Phosphorus & 283.50 & 317.00 & 389.50 & 401.00 & 363.5 \\
\hline
\end{tabular}

are not significantly greater than the upper limit of the range in question.

The percentages of protein content recorded for the five fish species also lie within the ranges quoted for seafood, including fin fishes, elsewhere. According to Sidwel (1981), the crude protein of seafood is between 8 and $25 \%$, while that of finfish muscle tissues ranges from 18 to $22 \%$. Fish protein, like most animal food, has excellent nutritive value because it has all the essential amino acids required by the human body (Love, 1980; Jhaveri et al., 1984; Nettleton, 1985; Pigott and Tucker, 1990; Huss, 1995; Clucas and Ward, 1996; Insel et al., 1998). The current finding on protein content suggests that each of the five fish species could be recommended as a source of first class protein especially to people suffering from protein energy malnutrition (Wardlaw et al., 1994).

The low fat content of four of the five species could be due to high level of activity (e.g. swimming) which might have utilized the fat as a source of energy (Wardlaw et al., 1994). Ackman (1989) categorized fish species into lean (species that store energy in the liver) or fatty (species that store lipids in fat depots throughout the body). According to them, the white muscle of cod (typical lean fish) contains less than $1 \%$ lipids of which phospholipids (structural lipids in cell membranes) make about 90\%. Lall (1994) reported that the fatty fish species include the pelagic ones such as mackerels tunas and sardines, while the lean fish species are the bottom-dwelling ones such as the soles and the rays. Thus the low (least of all the five) fat content recorded for the sole, a bottomdweller, corroborates this author's finding.

Lall (1994) also stated that the main difference between fish fat and mammalian one is that, fish lipids are highly unsaturated, while that of mammals is saturated, making the latter not suitable for human consumption. The low fat content suggests that these fish species could be recommended for people with problem of obesity. Another advantage of fish fat is the presence of omega-3-oil in it. This oil is a good source of vitamin A which is good for sustaining good eye-sight.

The lower carbohydrate content of $S$. japonicus (i.e. the least of all) suggests a higher metabolic rate of that species.

The minerals (calcium, iron and phosphorus) studied in the current research are among the major mineral elements contributing to the proper functioning of the human body, hence they are considered important dietary elements (Pye, 1986). The high concentrations of calcium and phosphorus compare favourably with those of dry skim milk and calf's brain that are recommended as good sources of calcium and phosphorus, respectively. The five fish species examined in this study could therefore be 
recommended as good sources of these two minerals.

In view of their first class protein contents, moderate and unsaturated fat contents moderate carbohydrate, coupled with the high mineral contents, of the five fish species studied, it may be concluded that all the five species are of high nutritional value and could be recommended for human consumption.

\section{ACKNOWLEDGEMENTS}

The authors are grateful to the Food Research Institute (CSIR) Accra, Ghana for supporting this research.

\section{REFERENCES}

Ackman RG. 1989. Nutritional composition in sea foods. Progress in Food and Nutrition Science, 13: 161-240.

AOAC. 1990. Official Methods Analysis (15 ${ }^{\text {th }}$ edn). Association of Official Analytical Chemists: Washington D.C.

Clucas J, Ward AR. 1996. Post Harvest Fisheries Development. A guide to Handling, Preservation, Processing and Quality. Chatham Maritime: Kentme 44 TB, UK.

FAO. 1986. Manuals of food quality control, food analysis; general techniques, additives, contaminants and composition. Food Nutrition Paper: 203-229.

Huss HH. 1995. Quality and Quality Changes in Fresh Fish. FAO Fisheries Technical Paper 348: Rome; 195p.

Insel MP, Dalton TR, Rollins L, Ray AP. 1998. Core Concept in Health. Mayfield Pub. Co: California; 190p.

Jhaveri SN, Karakoltsidis PA, Montecaluo L. 1984. Composition and Protein equality of some Southern New England marine species. Journal of Food Science, 49: 110-113.
Lall PS. 1994. Macro and trace elements in fish and shellfish. In Fish and Fishery Products, Composition, Nutritive Properties and Stabilities, Ruter (ed). Cab. International: UK; 187-197.

Love RM. 1980. The Chemical Biology of Fishes. Vol. 2. Academic Press: N.Y.; 227-278.

Nettleton JA. 1985. Seafood Nutrition: Facts, Issues and Marketing of Nutrition, in fish and shellfish. Osprey Books: Huntington, N.Y.

Nunes ML, Batisa I, Morcio de Campos R. 1992. Physical, chemical and sensory analysis of sardine (Sardine pilchardis) stored in ice. Journal of the Science of Food and Agriculture, 59: 37-43.

Ogunlade I, Olaofe O, Fadare T. 2005. Chemical composition, amino acids and functional properties of selected seafoods. Journal of Food, Agriculture and Environment, 3(2): 130-133.

Pigott GM, Tucker BW. 1990. Seafoods. Effects of Technology on Nutrition. Marcel Dekker Inc: N.Y.; 41-42.

Pye M. 1986. Success in nutrition. John Murray Ltd: London.

Sidwel VD. 1981. Chemical and Nutritional Composition of Fin fishes, Whales, Crustaceans, Mollusks and their Products. Technical Memorandum, Nutritional Oceanic and Administration, National Marine Fisheries Service, U.S. Department of Commerce: Washington D.C.; $43 p$.

Tenny FM, Ganhlitz EI, Hall ASA, Houle, CR. 1984. Mineral composition of edible muscle tissue of seven species of fish from the Northeast Pacific. Journal of Agriculture and Food Chemistry, 32: 852-855.

Wardlaw GM, Insel PM, Seyler MF. 1994. Contemporary Nutrition Issues and Insights ( $2^{\text {nd }}$ edn). Clarinda Co: USA. 